\title{
MODEL OF DECISION SUPPORT SYSTEM USED FOR ASSESSMENT OF INSURANCE RISK
}

\author{
Jelena Rusov \\ Dunav Insurance Company ado Belgrade \\ Mirjana Misita \\ University of Belgrade, Faculty of Mechanical Engineering, Belgrade, Serbia
}

In order to run a modern business in uncertain times, business forcasting is very important for evaluation of company's future financial performance. This paper shows an example of premium forecast based on the assessment of risk sources in insurance system. Due to uncertainty that is one of the characteristics of loss occurrence and indemnity amount, it is important to hold sufficient assets to cover the risk. For asset-liability matching, one should first assess the impact of risk on premium movement per insurance lines. This is the main concept of development and performance of insurance companies.

This paper shows an experimental research of risk ranking based on projected model of decision support system. Decision support system is used with the aim to generate hierarchy of influential criteria and alternatives of risk assessment model for stated insurance lines. Suggested model supports the idea according to which one should first determine insurance lines with the highest risk and then, on that basis, make a decision on premium amount in the following period.

Key words: Forecast, AHP, Risk assessment

\section{INTRODUCTION}

Using relationship between the values of income, expenses and profit to define business objectives is one of the main goals of business forecast in a certain period of time. Analysis of business forecast seeks to determine potentially critical periods which would require additional funding in order to secure continuous business operations.

Monitoring and forecasting of policy sale flow (premium) is very important for securing enough assets to cover the risk, meet the expenses and make profit. Forecasting of financial results is a basic development concept and one of the characteristics of insurance company operations. Forecasting stabilizes business operations, growth and development and improves the insurance market. In addition, it also provides complete protection of insured's interests.

Global movement and its influence on narrow and underdeveloped Serbian market, are undoubtedly very risky for company operations. In order to avoid, anticipate, reduce or mitigate the risks, the company should first perform risk identification, analysis and assessment.

A growing internationalization and concentration of insurance operations, emergence of new and dispersion of the existing risks call for a clear definition of solvency risk management policy in every insurance company. Risk represents the probability for occurrence of adverse effects on business and financial result and position of insurance company, while risk management is defined as the process of risk identification, measurement, assessment and control. Financial position and solvency of an insurer depend on insurance premium amount.

Analysis of insurance company operations and significance of business results forecasting were considered by Gestel et al. [04]. Sánchez used fuzzy regression to forecast one of the main expenses of insurance companies - claim reservation [8]. In addition, Shapiro [9] and Lemaire [6] pointed out the importance and application of fuzzy logic in insurance.

Chin-Sheng Huang et al. used AHP and fuzzy logic to suggest an assessment model when buying the policy of life or pension insurance since those insurance lines are among the major individual insurance lines [2]. Model was developed on the basis of experience of 5 insurance consultants, with minimum 3 years experience in insurance companies, where the inputs were: age, annual income, education and risk. 
AHP model is developed on the basis of questionnaire which contains expert's opinions regarding these two insurance lines. Fuzzy logic is used to form mapping of inputs, while AHP is used to generate weighted parameters for assessment model. Model from this study might be used to eliminate subjectivity of policy salespersons when making an offer to their clients.

Fouladvand and Darooneh used an example of motor vehicle insurance to formulate the model for forecast of insurance company annual income based on premium [3]. Model shows the premium amount when a company operates at a deficit. In addition, it provides detailed statistical analysis of company financial standing. Naimely, collected premium has to be sufficient to cover the insurance indemnity, cost of insurance service provision as well as realized profit. Also, the model predicts realized profit depending on the corresponding risk and premium amount. In addition, the model gives quanitified risk assessment based on premium increase. The link between the longterm company profit and insurance indicators, especially premium, is illustrated based on the obtained results.

This paper [7] shows an efficient use of intelligent systems for problem solving in voluntary health insurance. The model is based on neurofuzzy inference system (ANFIS) and it enables efficient determination of risk amount based on the interpretation of health factors of potential insureds with the set of fuzzy rules. Based on health factors such as age, occupation, history of disease, habits (smoker, alcohol consumer) and the like, it is possible to determine the risk of potential insured and consequently, the insurer would be able to determine the amount of insurance premium. Model determines the exposure of a potential insured to risk and that can be very useful for the insurers since they can determine the risk amount and consequently, the premium amount per policy.

Backović and Babić showed in practice how successful AHP method might be for reaching optimal decision regarding the selection of the most afordable life insurance policy [1]. Model provides numerous possibilities, therefore, alternatives might be compared per one criterion or few criteria, depending on the decision maker preferences. Also, insurance companies might use the model to make a comparison with the competition, as well as to discover its own weaknesses that should be improved in order to attract the clients. This paper shows that multi-criteria analysis, when selecting the most afordable insurance policy, undoubtedly provides a solution based on the authentic data from insurance companies.

\section{DEVELOPING RISK ASSESSMENT MODEL AND INSURANCE PREMIUM FORECAST}

An insurance company has to monitor risks per insurance lines (life and non-life insurance). Measuring, i.e. risk assessment, should be done by the insurer through qualitative and quantitative assessment of identified risks and events. The risks should be classified according to their impact on overall risk. When an insurance company sells the policy, it grants that it is able to assume the risk through its technical and financial capacities.

Risk management implies identification, measurement, assessment and control of risk in company operations. In order to provide company solvency, i.e. in order to enable the company to provide adequate indemnity for all claims, it is necessary to manage the risks in a manner that would provide general and preventive risk identification and permanent maintenance of a degree of risk exposures which is not threatening to property and business operations. Therefore, this paper deals with forecast and profit management through the application of basic risks present on the market. Forecast and profit management are directly dependant on policy sales per insurance lines.

Basic risk groups included in the model are the following:

- insurance risk (R1),

- market risk (R2),

- fraud risk (R3),

- solvency and liquidity risk (R4),

- legal risk (R5) and

- environment risk (R6).

Each of the aforementioned risks includes a set of subrisks, defined by the Rulebook on insurance company risk management $/ 9 /$, which are graded and included in weighted grade of the stated risk. Within the basic risk group there is a set of subrisks that are being separately assessed. Regarding the insurance risk, the following risks are explained in details: risk of inadequate insurance premium level (R11), risk of inadequate assessment of the insured risk 
(R12), risk of inadequately set retention limit of the company (R13), risk of unmatched and damaging tariff policy of the company regarding risk dispersion (R14), risk of inadequate specification of insurance terms (R15) and risk of inadequate allocation of technical reserves (R16).

The second group of risks is divided into the competition risk regarding the premium amount-scope of cover (R21) and the risk of disloyal competition when participating in public tender biddings (R22). The risk of fraud, the third group of risks, is divided into the risk of assessment, settlement and indemnity payment (R31) and risk of collection of recourse and other debts (R32). Legal risk means the risk of losses arising from insurance and other disputes, failure to collect debt and other risks. Regarding the abovementioned subgroups, only subrisks that relate to risk of inadequately defined insurance premium are further divided.

Given that all the necessary risks are defined, decision support system is used to develop decision model. Figure 1 shows the hierarchy structure of risk source.

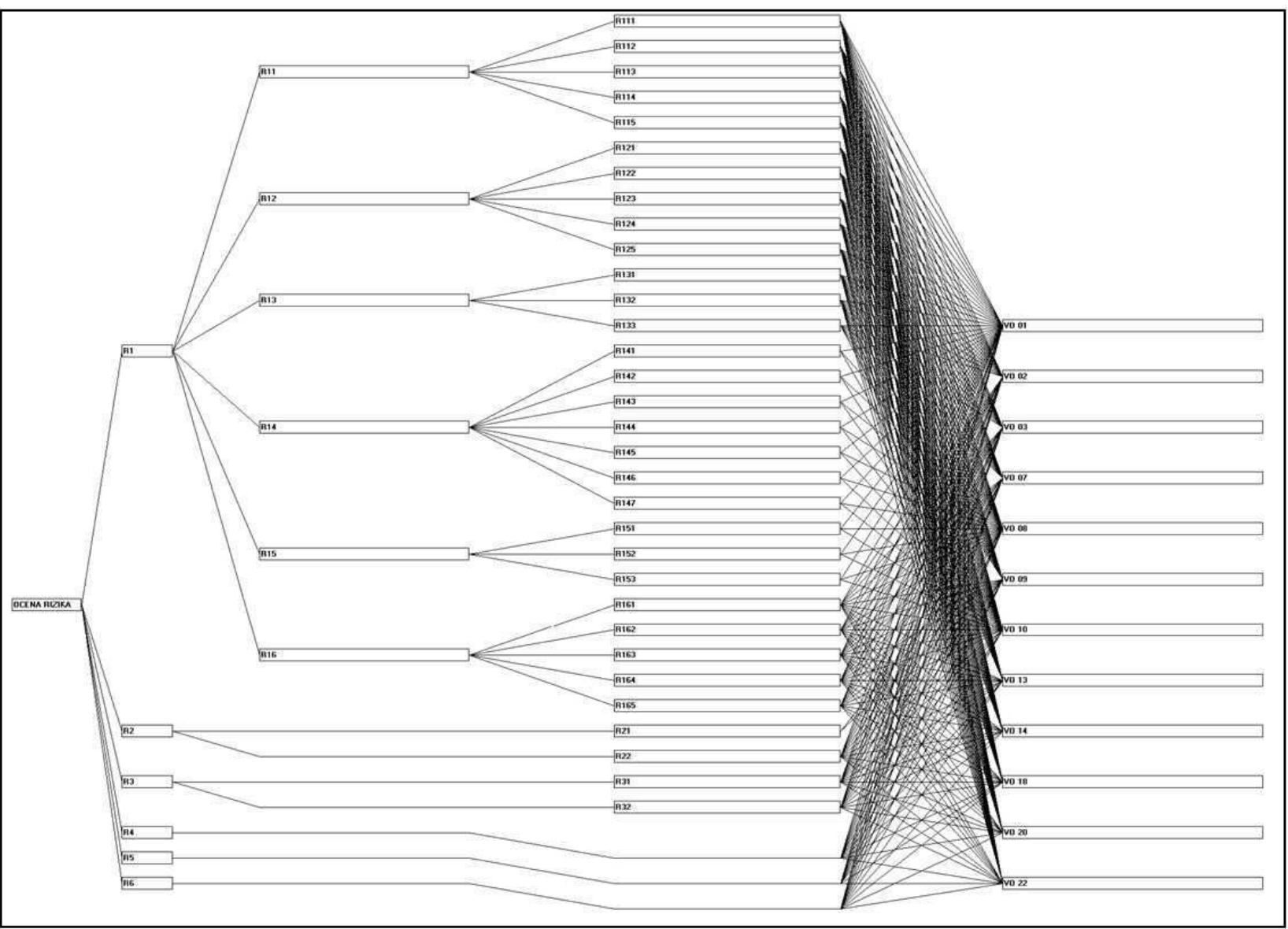

Figure 1: Hierarchy for risk assessment used for insurance premium forecasting

After having defined the hierarchical structure, it is important to assess the risk impact on insurance lines that are being analyzed: 01 -Accident Insurance, 02 - Voluntary Health Insurance, 03 - Motor Vehicle Insurance, 07 - Goods in Transit Insurance, 08 - Property Insurance against Fire and Allied perils, 09 - Other Property Insurance Lines, 10 - Motor Vehicle Liability Insurance, 13 - General Liability Insurance, 14 - Credit Insurance, 18 - Road Assistance Insurance, 20 - Life Insurance and 22 - Supplementary Insurance along with Life Insurance (according to the
Codes of the National Bank of Serbia).

Risk levels are determined through the application of matrix model for measuring of identified risks. Model uses, among other things, results obtained through the process of assessment, by applying the corresponding weighting system. Numercal scale is used for allocation of weighted risk assessment, where 1 means low risk while 10 defines extreme risk. Naimely, formed risk matrix consists of columns (insurance lines) and rows (management and financial risks) while the 
elements of matrix are numerically defined and they represent assessment of risk impact on insurance lines.

The values of defined risks are given based on risk impact on policy sale and premium in the period from 2008 to 2014 with the application of
AHP technique (Analytical Hierarchy Process). AHP is a multi-criteria technique which decomposes the complex problem into a hierarchy.

Assessment of alternatives for a specific example of a company - insurance company, per identified risk sources (R1-R-32) is shown in Table 1.

Table 1: Assessment of risk sources

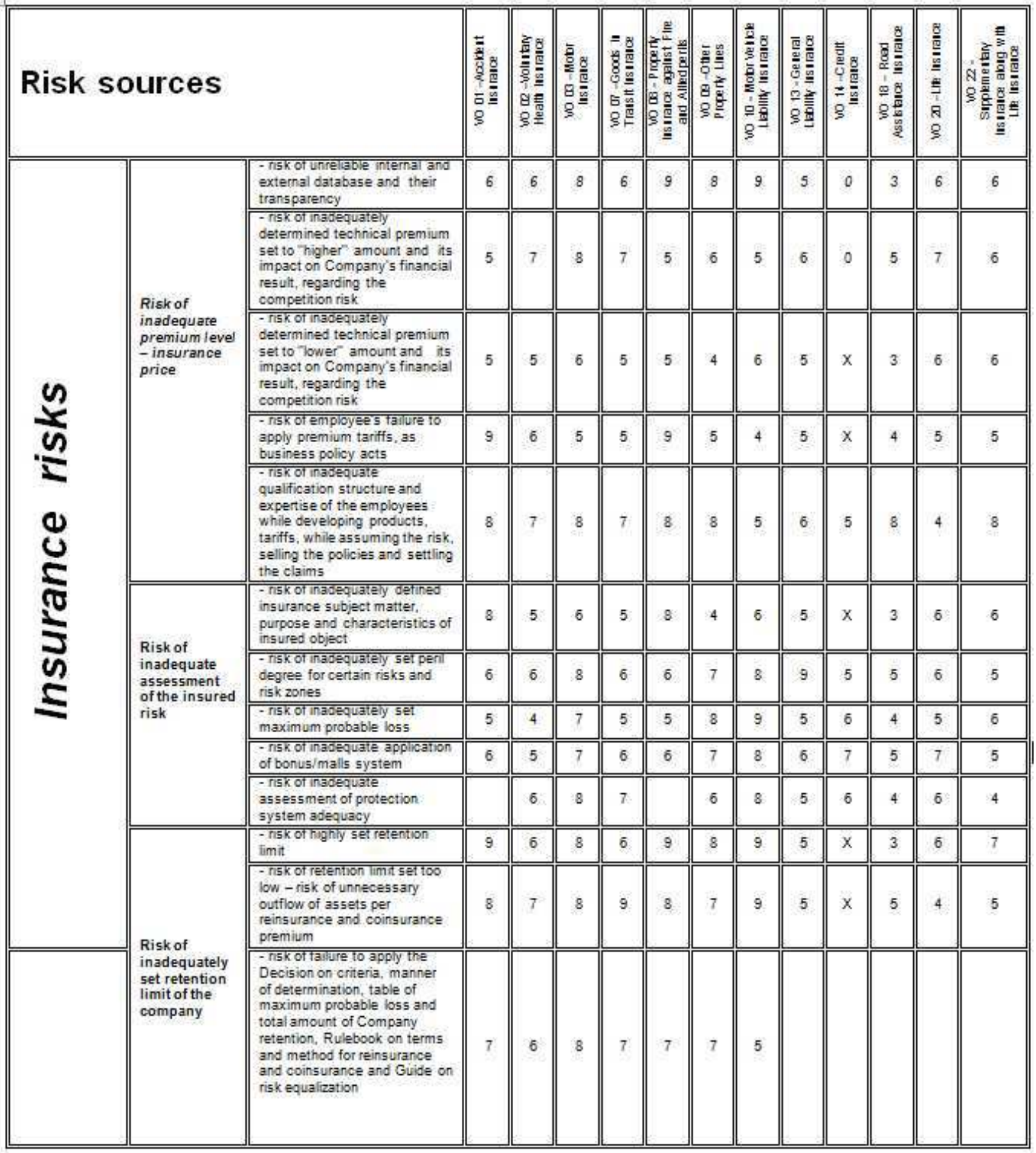


Table 1: Assessment of risk sources

\begin{tabular}{|c|c|c|c|c|c|c|c|c|c|c|c|c|c|c|}
\hline \multirow{15}{*}{$\frac{1}{10}$} & \multirow{7}{*}{$\begin{array}{l}\text { Risk of } \\
\text { unmatched, } \\
\text { unadjusted } \\
\text { and } \\
\text { economically } \\
\text { damaging } \\
\text { tariff } \\
\text { policy of the } \\
\text { company }\end{array}$} & $\begin{array}{l}\text { - rlsk of not having insurance } \\
\text { costs covered by collected } \\
\text { loading for expense }\end{array}$ & 10 & & & & 10 & & 6 & & & & & \\
\hline & & $\begin{array}{l}\text { - risk of inadequate insurance } \\
\text { costs management }\end{array}$ & 10 & & & & 10 & & 4 & & & & & \\
\hline & & $\begin{array}{l}\text { - risk of inadequate combined } \\
\text { ratio }\end{array}$ & & & & & & & 5 & & & & & \\
\hline & & $\begin{array}{l}\text { - risk of inability to collect the } \\
\text { premium }\end{array}$ & 9 & & & & 9 & & 6 & & & & & \\
\hline & & $\begin{array}{l}\text { - risk of nability to direclly } \\
\text { allocate the insurance costs } \\
\text { per tariffs, i.e. insurance types } \\
\text { (risk of using keys for } \\
\text { allocation of expenses) }\end{array}$ & 8 & & & & 8 & & 8 & & & & & \\
\hline & & $\begin{array}{l}\text { - nisk of premium payment } \\
\text { method }\end{array}$ & 6 & & & & 6 & & 9 & & & & & \\
\hline & & $\begin{array}{l}\text { - risk of nadequate insurance } \\
\text { premium structure and } \\
\text { reinsurance per insurance } \\
\text { agreements with provided } \\
\text { reinsurance cover }\end{array}$ & 8 & & & & 8 & & 8 & & & & & \\
\hline & \multirow{3}{*}{$\begin{array}{l}\text { Risk of } \\
\text { inadequate } \\
\text { specification } \\
\text { of general, } \\
\text { specific, } \\
\text { additional or } \\
\text { individual } \\
\text { terms of } \\
\text { insurance }\end{array}$} & $\begin{array}{l}\text { - risk of mismatch between the } \\
\text { terms and premium tariff }\end{array}$ & 10 & & & & 10 & & 8 & & & & & \\
\hline & & $\begin{array}{l}\text { - risk of mismatch whth legal } \\
\text { provisions }\end{array}$ & 4 & & & & 4 & & 9 & & & & & \\
\hline & & $\begin{array}{l}\text { - nsk of imprecisely defined } \\
\text { insurance terms, insurance } \\
\text { subject matter, insured risks, } \\
\text { exclusions and limitations of } \\
\text { insurer's liability }\end{array}$ & 7 & & & & 7 & & & & & & & \\
\hline & \multirow{5}{*}{$\begin{array}{l}\text { Risk of } \\
\text { inadequate } \\
\text { allocation of } \\
\text { all technical } \\
\text { reserves }\end{array}$} & $\begin{array}{l}\text { - risk of inadequate calculation } \\
\text { of unearned premium }\end{array}$ & 4 & 1 & 7 & 1 & 5 & 7 & 9 & 3 & 1 & $i$ & $x$ & $x$ \\
\hline & & $\begin{array}{l}\text { - risk of inabequate } \\
\text { reservation of incurred but } \\
\text { reported losses }\end{array}$ & 2 & 1 & 3 & 2 & 5 & 6 & 9 & 4 & $x$ & 1 & 1 & 1 \\
\hline & & $\begin{array}{l}\text { risk of inadequate calculation } \\
\text { of reserves for incurred but not } \\
\text { reported losses }\end{array}$ & 8 & 2 & 7 & 1. & 5 & 8 & 9 & 5 & 1 & 2 & $x$ & 1 \\
\hline & & $\begin{array}{l}\text { - nisk of inadequate calculation } \\
\text { of reserves for risk } \\
\text { equalization }\end{array}$ & 7 & $x$ & 2 & 5 & $x$ & 2 & 9 & 5 & 3 & $x$ & $x$ & $\mathrm{x}$ \\
\hline & & $\begin{array}{l}\text { - n5k of inacequate calculation } \\
\text { of mathematical reserve }\end{array}$ & $\mathrm{x}$ & $x$ & $x$ & $x$ & $x$ & $x$ & $x$ & $x$ & $x$ & $x$ & 10 & 1 \\
\hline \multirow{2}{*}{\multicolumn{2}{|c|}{ Market Risk }} & $\begin{array}{l}\text { - competence nsk regarding } \\
\text { the premium amount - scope } \\
\text { of cover }\end{array}$ & & & & & 9 & 9 & & & & & & \\
\hline & & $\begin{array}{l}\text { - risks of disioyal competition } \\
\text { while taking part in public } \\
\text { tender biddings }\end{array}$ & 9 & $\mathrm{x}$ & 8 & $x$ & 9 & 9 & 5 & 9 & $x$ & $x$ & $x$ & $\mathrm{x}$ \\
\hline \multirow{2}{*}{\multicolumn{2}{|c|}{ Fraud Risk }} & $\begin{array}{l}\text { - assessment, sertlement and } \\
\text { indemnity payment }\end{array}$ & 7 & 3 & 6 & 1 & 2 & 8 & 5 & 2 & 1 & 3 & 4 & 2 \\
\hline & & $\begin{array}{l}\text { - collection of recenvables ando } \\
\text { other debts }\end{array}$ & 1 & 1 & 6 & 1 & 4 & 5 & 7 & 9 & 10 & 1 & 1 & 1 \\
\hline \multicolumn{2}{|c|}{ Solvency and Liquidity Risk } & $\begin{array}{l}\text { - risk of inadequate cover of } \\
\text { excess risk with coinsurance } \\
\text { i.e. reinsurance }\end{array}$ & 9 & 2 & 8 & 3 & 4 & 9 & 1 & 2 & 1 & 1 & 1 & 1 \\
\hline \multicolumn{2}{|c|}{ Legal Risk } & $\begin{array}{l}\text {-nsk of losses ansing from } \\
\text { disputes regarding insurance } \\
\text { and other disputes, failure to } \\
\text { collect recourse and other } \\
\text { basis }\end{array}$ & 5 & 1 & 3 & 1 & 2 & 2 & 9 & 4 & $x$ & 1 & $\mathrm{x}$ & 1 \\
\hline \multicolumn{2}{|c|}{ Environmental Risk } & & 3 & 3 & 3 & 3 & 6 & 6 & 2. & 6 & 6 & 5 & 9 & 9 \\
\hline
\end{tabular}

\section{RESULTS AND ANALYSIS}

Application of AHP method generated synthesized results shown in Table 2. 
Table 2: Results: Weighted assessment of insurance lines per risk sources

\begin{tabular}{|c|c|c|c|c|c|c|c|c|c|c|c|c|c|}
\hline $\begin{array}{l}\text { Lowest } \\
\text { Level }\end{array}$ & $\begin{array}{l}\text { VO } \\
01\end{array}$ & VO 22 & VO 20 & VO 18 & VO 14 & $\begin{array}{l}\text { VO } \\
13\end{array}$ & $\begin{array}{l}\text { VO } \\
10\end{array}$ & $\begin{array}{l}\text { VO } \\
09\end{array}$ & $\begin{array}{l}\text { VO } \\
08 \\
\end{array}$ & $\begin{array}{l}\text { VO } \\
07 \\
\end{array}$ & $\begin{array}{l}\mathrm{VO} \\
03 \\
\end{array}$ & $\begin{array}{l}\mathrm{VO} \\
02 \\
\end{array}$ & $\begin{array}{c}\text { Model } \\
\text { Weights }\end{array}$ \\
\hline R165 & 0,065 & 0,032 & 0,323 & 0,065 & 0,065 & 0,065 & 0,065 & 0,065 & 0,065 & 0,065 & 0,065 & 0,065 & 0,007 \\
\hline R6 & 0,049 & 0,148 & 0,148 & 0,082 & 0,098 & 0,098 & 0,033 & 0,098 & 0,098 & 0,049 & 0,049 & 0,049 & 0,158 \\
\hline R5 & 0,172 & 0,034 & $\ldots$ & 0,034 & $\ldots$ & 0,138 & 0,31 & 0,069 & 0,069 & 0,034 & 0,103 & 0,034 & 0,158 \\
\hline R4 & 0,214 & 0,024 & 0,024 & 0,024 & 0,024 & 0,048 & 0,024 & 0,214 & 0,095 & 0,071 & 0,19 & 0,048 & 0,158 \\
\hline R153 & 0,368 & $\ldots$ & $\ldots$ & $\ldots$ & $\ldots$ & $\ldots$ & 0,263 & $\ldots$ & 0,368 & $\ldots$ & $\ldots$ & $\ldots$ & 0,012 \\
\hline R147 & 0,333 & 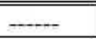 & ב-.... & ב-.... & 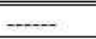 & ב-w & 0,333 & $+\ldots$ & 0,333 & 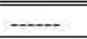 & ב-ב- & ב-1- & 0,005 \\
\hline R133 & 0,149 & $\ldots$ & $\ldots$ & $\ldots$ & $\ldots$ & $\ldots$ & 0,106 & 0,149 & 0,149 & 0,149 & 0,17 & 0,128 & 0,012 \\
\hline R125 & 0,071 & 0,057 & 0,086 & 0,057 & 0,086 & 0,071 & 0,114 & 0,086 & 0,071 & 0,1 & 0,114 & 0,086 & 0,007 \\
\hline R115 & 0,098 & 0,098 & 0,049 & 0,098 & 0,061 & 0,073 & 0,061 & 0,098 & 0,098 & 0,085 & 0,098 & 0,085 & 0,007 \\
\hline R114 & 0,134 & 0,075 & 0,075 & 0,06 & 0,075 & 0,075 & 0,06 & 0,075 & 0,134 & 0,075 & 0,075 & 0,09 & 0,007 \\
\hline R113 & 0,082 & 0,098 & 0,098 & 0,049 & 0,082 & 0,082 & 0,098 & 0,066 & 0,082 & 0,082 & 0,098 & 0,082 & 0,007 \\
\hline R112 & 0,075 & 0,09 & 0,104 & 0,075 & 0 & 0,09 & 0,075 & 0,09 & 0,075 & 0,104 & 0,119 & 0,104 & 0,007 \\
\hline R111 & 0,083 & 0,083 & 0,083 & 0,042 & 0 & 0,069 & 0,125 & 0,111 & 0,125 & 0,083 & 0,111 & 0,083 & 0,007 \\
\hline R121 & 0,119 & 0,09 & 0,09 & 0,045 & 0,075 & 0,075 & 0,09 & 0,06 & 0,119 & 0,075 & 0,09 & 0,075 & 0,007 \\
\hline R124 & 0,08 & 0,067 & 0,093 & 0,067 & 0,093 & 0,08 & 0,107 & 0,093 & 0,08 & 0,08 & 0,093 & 0,067 & 0,007 \\
\hline R123 & 0,072 & 0,087 & 0,072 & 0,058 & 0,087 & 0,072 & 0,13 & 0,116 & 0,072 & 0,072 & 0,101 & 0,058 & 0,007 \\
\hline R122 & 0,078 & 0,065 & 0,078 & 0,065 & 0,065 & 0,117 & 0,104 & 0,091 & 0,078 & 0,078 & 0,104 & 0,078 & 0,007 \\
\hline R132 & 0,1 & 0,063 & 0,05 & 0,063 & 0,063 & 0,063 & 0,112 & 0,087 & 0,1 & 0,112 & 0,1 & 0,087 & 0,012 \\
\hline R131 & 0,111 & 0,086 & 0,074 & 0,037 & 0,062 & 0,062 & 0,111 & 0,099 & 0,111 & 0,074 & 0,099 & 0,074 & 0,012 \\
\hline R141 & 0,385 & 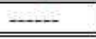 & $\ldots$ & $\ldots$ & $\cdots$ & $\cdots$ & 0,231 & $\cdots$ & 0,385 & $\cdots$ & $\ldots$ & $\ldots$ & 0,005 \\
\hline R146 & 0,286 & ב-... & + & ב-.... & ב-1... & $\ldots$ & 0,429 & $+\ldots$ & 0,286 & 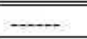 & ב-1.. & ב-1.. & 0,005 \\
\hline R145 & 0,333 & ב..... & $\ldots$ & 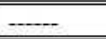 & ב..... & ב-.... & 0,333 & ב-.... & 0,333 & $\ldots$ & ב-ב- & 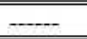 & 0,005 \\
\hline R144 & 0,375 & $\ldots$ & $\cdots$ & $\ldots$ & $\cdots$ & $\ldots$ & 0,25 & $\cdots$ & 0,375 & $\ldots$ & $\ldots$ & $\ldots$ & 0,005 \\
\hline R143 & 0,333 & $\ldots$ & $\ldots$ & $\ldots$ & $\ldots$ & ב-... & 0,333 & $\ldots$ & 0,333 & 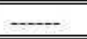 & $\ldots$ & $\ldots$ & 0,005 \\
\hline R142 & 0,417 & $\ldots$ & $\ldots$ & $\ldots$ & $\ldots$ & $\ldots$ & 0,167 & $\ldots$ & 0,417 & $\ldots$ & $\ldots$ & $\ldots$ & 0,005 \\
\hline R152 & 0,235 & $\ldots$ & +n & $\ldots$ & $\ldots$ & $\ldots$ & 0,529 & $\ldots$ & 0,235 & $\ldots$ & $\ldots$ & $\ldots$ & 0,012 \\
\hline R151 & 0,357 & $\ldots$ & $\ldots$ & $\ldots$ & $\ldots$ & $\ldots$ & 0,286 & $\ldots$ & 0,357 & $\ldots$ & $\ldots$ & $\ldots$ & 0,012 \\
\hline R164 & 0,121 & 0,086 & 0,086 & 0,086 & 0,052 & 0,086 & 0,155 & 0,034 & 0,086 & 0,086 & 0,034 & 0,086 & 0,007 \\
\hline R163 & 0,148 & 0,019 & 0,093 & 0,037 & 0,019 & 0,093 & 0,167 & 0,148 & 0,093 & 0,019 & 0,13 & 0,037 & 0,007 \\
\hline R162 & 0,05 & 0,025 & 0,025 & 0,025 & 0,125 & 0,1 & 0,225 & 0,15 & 0,125 & 0,05 & 0,075 & 0,025 & 0,007 \\
\hline R161 & 0,082 & 0,102 & 0,102 & 0,02 & 0,02 & 0,061 & 0,184 & 0,143 & 0,102 & 0,02 & 0,143 & 0,02 & 0,007 \\
\hline R22 & 0,114 & 0,063 & 0,063 & 0,063 & 0,063 & 0,114 & 0,063 & 0,114 & 0,114 & 0,063 & 0,101 & 0,063 & 0,079 \\
\hline R21 & $\ldots$ & $\ldots$ & $\ldots$ & $\ldots$ & $\ldots$ & $\ldots$ & $\ldots$ & 0,5 & 0,5 & $\ldots$ & $\ldots$ & $\ldots$ & 0,079 \\
\hline R32 & 0,021 & 0,021 & 0,021 & 0,021 & 0,213 & 0,191 & 0,149 & 0,106 & 0,085 & 0,021 & 0,128 & 0,021 & 0,079 \\
\hline R31 & 0,159 & 0,045 & 0,091 & 0,068 & 0,023 & 0,045 & 0,114 & 0,182 & 0,045 & 0,023 & 0,136 & 0,068 & 0,079 \\
\hline Results & 0,129 & 0,052 & 0,053 & 0,041 & 0,051 & 0,082 & 0,123 & 0,145 & 0,138 & 0,044 & 0,098 & 0,043 & \\
\hline
\end{tabular}

Risk impact on key insurance lines might be ranked based on the results. According to data from Table 2, it can be concluded that insurance risk - R1 has the most impact on stated insurance lines, which stems from the assessment of its subrisks. However, a special attention should be paid to liquidity risk - R4 even though it is not highly ranked. The liquidity risk represents the possibility that the company, due to lack of funds, becomes insolvent and has difficulties paying the indemnity. Therefore, premium collection should be improved in order to mitigate the risk. Figure 2 shows the results i.e. the ranking of 12 insurance lines listed from the most significant to the least significant regarding the first level of criteria (basic risk groups). The figure clearly demonstrates that property insurance lines (08 and 09 ), with total priority of 0,283 are the dominant ones in relation to other insurance lines, i.e. the majority of stated risks have the strongest impact on those insurance lines. The third place is reserved for Accident insurance with priority of 0,129 , while Motor Third Party Liability Insurance is in fourth place. These four types are the dominant ones with the total priority amounting to $54 \%$, which means that those insurance lines make the most part of portfolio, i.e. they have the greatest number of policies and consequently, they have the greatest premium collection.

The following diagram shows the structure of risks that have impact on insurance lines, Figure 3. Insurance lines might be considered according to certain risks which brings us to various conclusions. Sensitivity graphs show the degree of significance of a certain insurance line in relation to other lines within the model. Significance degree is obtained according to the sensitivity of results. The diagram brings us to a conclusion that if we give less significance to a certain risk in relation to other risks, the ranking of insurance lines will be changed in terms of the risks included in the model (as shown in Figure 2). 


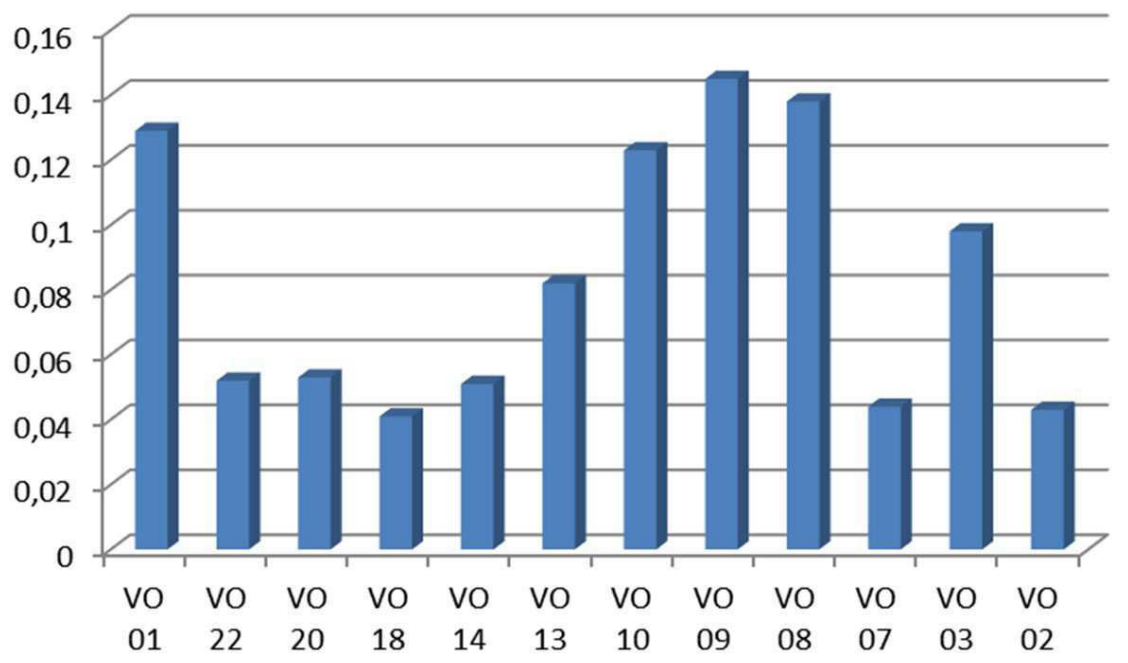

Figure 2: Ranking of insurance lines according to their significance in terms of first level risks

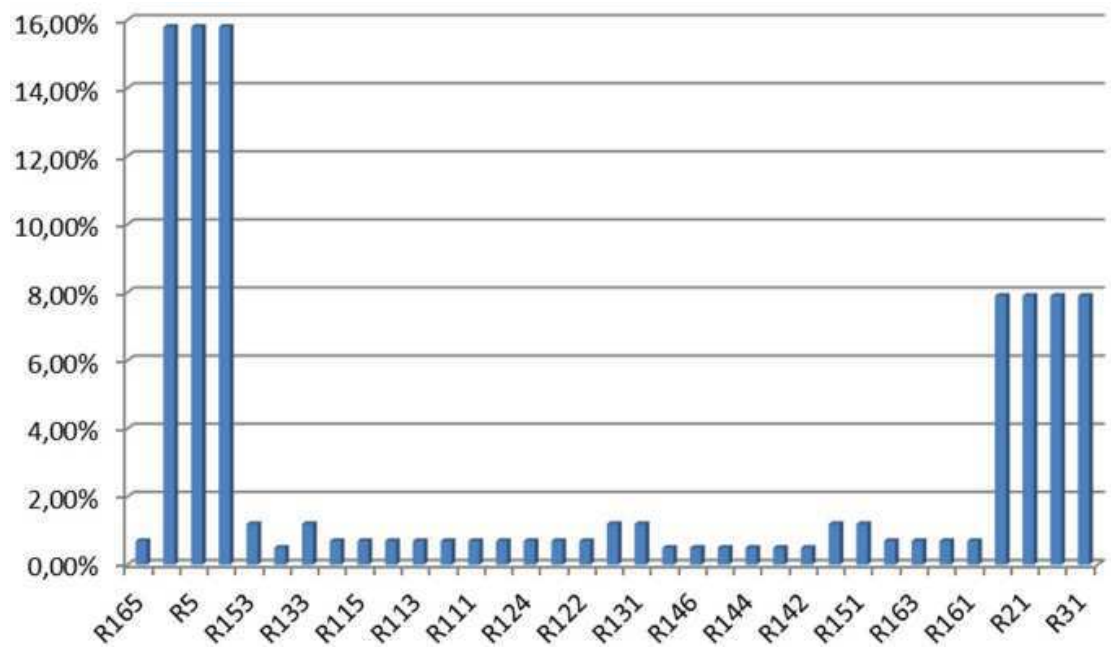

Figure 3: Percentage share of risk sources per all insurance lines

It is necessary to control basic risks. In order to avoid bad results, it is necessary to make good risk assessment, especially the assessment of first level risks. Sensitivity analysis determines the impact of risks on insurance lines. This analysis shows the impact on policy sale per insurance lines depending on the change of risks used for model assessment. Diagrams allow decision maker to analyse whether within the given assessment, there is a potential overlapping of insurance lines. In case of a slight variation in assessment of significance of certain risk, such overlapping would indicate the change in structure of analysed results.

Each of the stated risks is of utmost importance for company operations. In order to prevent operational risks, an insurance company should transfer the assets into various forms of reserves. In this regard, premium is the main source of assets. The risk of model unreliability represents the risk that the expected premium value will be incorrectly determined due to mistakenly selected statistical distribution which approximates the premium flow. The dynamics of risk change that impacts the premium adequacy should be continually monitored. Analysis of the results shows that for the existing risk groups among stated insurance lines, the insurance lines 09, 08, 01, 10,03 and 13 are expected to have the biggest increase in forecasted premium in the following year.

\section{CONCLUSION}

Insurance companies act as institutional investors in financial system of a country. Risk dispersion is an important segment of their business. Accordingly, this paper analyses prediction mechanisms and demonstrates how their application in insurance companies' operations may decrease the risk of illiquidity. 
Decision support system is used to generate the hierarchy of influential criteria and alternatives in the risk assessment model regarding the stated insurance lines. Suggested model supports the idea according to which one should first determine insurance lines with the highest risk and then, on that basis, make a decision on premium amount in the following period.

\section{REFERENCES}

1) Backović, M., Babić, S., (2013)

Višekriterijumska optimizacija postupka izbora najpovoljnije polise životnog osiguranja, Economics \& Economy, Vol. 1, No. 1, 41-66.

2) Chin-Sheng Huang, Yu-Ju Lin, Che-Chern Lin (2007) An Evaluation Model for Determining Insurance Policy Using AHP and Fuzzy Logic: Case Studies of Life and Annuity Insurances, Proceedings of the 8th WSEAS International Conference on Fuzzy Systems, Vancouver, British Columbia, Canada, June 19-21.

3) Fouladvand E., M., Darooneh, A. H., (2005) Premium Forecasting of an Insurance Company: Automobile Insurance, International Journal of Modern Physics, Vol. 16, No 3, 377-387.

4) Gestel, T., V., Martens, D., Baesens, B., Feremans, D., Huysmans, J., Vanthienen, J. (2007): Forecasting and analyzing insurance companies' ratings, International Journal of Forecasting, Vol. 23, Issue 3, pp. 513-529.

5) http://www.nbs.rs/export/sites/default/internet/latinica/20/sistem_internih_kontrola.pdf, downloaded on 6th March, 2015

6) Lemaire. J, (1990) Fuzzy Insurance,ASTIN Bulletin 20.1, pp. 33-55.

7) Nidhi A., Vij S. K, (2013) Reckoner for health risk and insurance premium using adaptive neurofuzzy inferences system, Neural Comput \& Applic 23, 2121-2128.

8) Sánchez, J., A. (2006) Calculating insurance claim reserves with fuzzy regression, Fuzzy Sets and Systems, Vol. 157, Issue 23, pp. 3091-3108.

9) Shapiro., A., F., (2004) Fuzzy logic in insurance, Insurance: Mathematics and Economics 35.2, pp. 399-424.

Paper sent to revision: 08.12.2015.

Paper ready for publication: 15.03.2016. 
MODEL SISTEMA ZA PODRŠKU ODLUČIVANJU KORIŠĆEN ZA OCENU RIZIKA U OSIGURAVAJUĆOJ KOMPANIJI

\author{
Jelena Rusov, Dunav Osiguranje ado Beograd \\ Mirjana Misita, Univerzitet u Beogradu, Mašinski fakultet, Beograd
}

Za savremeno poslovanje u uslovima neizvesnosti, rezultati predviđanja poslovanja su od suštinskog značaja za evaluaciju buduće finansijske efikasnosti preduzeća. U radu je izložen primer predviđanja premija na osnovu ocena izvora rizika u osiguranju. Zbog neizvesnosti koja prati trenutak nastanka $i$ iznosa štete neophodno je osigurati dovoljno sredstava za pokriće rizika. Za usklađivanje sredstava $i$ obaveza potrebno je oceniti uticaj rizika na promenu premije po vrstama osiguranja, što čini osnovni koncept razvoja i poslovanja osiguravajućih društava.

$U$ radu je predstavljeno eksperimentalno istraživanje rangiranja rizika na osnovu projektovanog modela u sistemu za podršku odlučivanju. Sistem za podršku odlučivanju korišćen je u cilju generisanja hijerarhije uticajnih kriterijuma i alternativa u modelu za ocenu rizika kod navedenih vrsta osiguranja. Predloženi model zagovara ideju da se za vrste osiguranja kod koje se utvrdi najviši stepen rizika $i$ na osnovu toga donesu odluke o visini premije u narednom periodu.

Ključne reči: predviđanje, AHP, ocena rizika 